Biogeosciences Discuss., https://doi.org/10.5194/bg-2017-408

Manuscript under review for journal Biogeosciences

Discussion started: 23 October 2017

(c) Author(s) 2017. CC BY 4.0 License.

\title{
Variations in soil carbon, nitrogen, phosphorus and stoichiometry along forest succession in southern China
}

Shuai Ouyang ${ }^{1,2}$, Wenhua Xiang ${ }^{1,2, *}$, Mengmeng Gou ${ }^{3}$, Pifeng Lei ${ }^{1,2}$, Liang Chen ${ }^{1,2}$, Xiangwen Deng ${ }^{1,2}$, Zhonghui Zhao ${ }^{1,2}$

${ }^{1}$ Faculty of Life Science and Technology, Central South University of Forestry and Technology, Changsha, Hunan, 410004 , China

${ }^{2}$ Huitong National Station for Scientific Observation and Research of Chinese Fir Plantation Ecosystems in Hunan Province, Huitong, Hunan 438107, China

${ }^{3}$ Chinese Research Academy of Environmental Science, Beijing, 100012, China

Corresponding to: Wenhua Xiang (xiangwh2005@163.com)

Abstract. Floristic composition changes during forest succession influence nutrient cycling. However, variation patterns of soil carbon $(\mathrm{C})$, nitrogen $(\mathrm{N})$, and phosphorous $(\mathrm{P})$, and soil stoichiometry $(\mathrm{C}: \mathrm{N}, \mathrm{C}: \mathrm{P}$, and $\mathrm{N}: \mathrm{P}$ ratios) along forest succession are controversial. In this study, soil samples were collected at depths of $0-10,10-20$, and $20-30 \mathrm{~cm}$ in three forests at early, middle, and late succession stages. Concentrations of soil organic carbon (SOC), total nitrogen (TN), and total phosphorus (TP) were measured. As succession proceeds, concentrations and storage of SOC and TN exhibited a significant increasing tendency, while those of TP decreased significantly. The tendency was more pronounced $(\mathrm{P}<0.05)$ in soil depths of $0-10 \mathrm{~cm}$, implying that more SOC, TN, and TP were stored in the upper soil layer. The ratios of soil C:P and N:P increased far more than the $\mathrm{C}: \mathrm{N}$ ratio with succession progress, indicating that forests in this region were primarily limited by $\mathrm{P}$ over time. The $\mathrm{C}: \mathrm{N}, \mathrm{C}: \mathrm{P}$, and N:P ratios decreased from the upper to lower soil layers at almost all succession stages. A significantly positive correlation was found between the SOC, TN, and TP concentrations $(\mathrm{P}<0.05)$, implying a relatively constrained C:N:P ratio in this subtropical forest soil. Stand density, litter, soil bulk density, $\mathrm{pH}$, texture, and elevation significantly affected SOC, TN, and TP concentrations and their storage. The effects of succession stage, stand density, soil depth, and soil properties on soil nutrient balance should be considered in future studies. 
Biogeosciences Discuss., https://doi.org/10.5194/bg-2017-408

Manuscript under review for journal Biogeosciences

Discussion started: 23 October 2017

(c) Author(s) 2017. CC BY 4.0 License.

\section{Introduction}

Soil organic carbon (SOC), total nitrogen (TN), and total phosphorus (TP) are very important indicators of soil fertility and productivity (Chapin, 2003; Andrews et al., 2004; Jiménez et al., 2011). For instance, SOC directly affects the production capacity of ecosystems, and acts as an indicator of ecosystem response to the environment (Chapin, 2003). Soil $\mathrm{N}$ and $\mathrm{P}$ are the main nutrient elements for plant growth, which affect photosynthesis and other processes associated with primary production (Quilchano et al., 2008; Liu et al., 2013). Furthermore, soil N and P cycles are closely correlated with SOC cycles (Gao et al., 2014), and have the potential to mitigate the effects of global climate change (Lal, 2004; IPCC, 2007; Sardans et al., 2012). Soil stoichiometry (C:N:P ratios) is a good indicator of soil nutrient status, and is widely used as a powerful tool to advance our understanding of the interactions between the above-ground plant community and below-ground soil nutrient characteristics in terrestrial ecosystems (Mooshammer et al., 2014; Zechmeister-Boltenstern et al., 2015). Therefore, a better understanding of the variations in SOC, N, P, and soil stoichiometry is important to assess soil nutrient status in forest ecosystems and sustainable development.

The concentrations and distribution of soil $\mathrm{C}, \mathrm{N}$, and $\mathrm{P}$ can differ between diverse plant communities due to different chemical traits and amount of litter and root returned to the soil (Zhao et al., 2010; Deng et al., 2013). Recent studies suggest that forest succession, caused by both natural succession and management activity, could improve the soil C sequestration capacity (Chang et al., 2011; Deng et al., 2013). However, to date, general relationships between soil N and P variations and forest succession remains controversial. Studies have found that $\mathrm{N}$ increases (Deng et al., 2014) or decreases (Bond-Lamberty et al., 2006) with forest succession. Following succession, soil P has been found to decrease (Chen et al., 2000), increase (Wang et al., 2011), or remain unchanged (Wen et al., 2005).

It is anticipated that soil stoichiometry $(\mathrm{C}: \mathrm{N}: \mathrm{P})$ will change with forest succession, due to changes in species composition, biomass production, and soil properties (Deng et al., 2013; Fanin et al., 2013). In recent years, more studies have been conducted to examine soil stoichiometry changes during secondary forest succession in the northern Loess Plateau, China (Jia et al., 2012; Deng et al., 2013; 2014). However, in subtropical southern China, while several studies have investigated changes in stoichiometry in the tissues of aboveground vegetation in secondary forests, soil stoichiometry dynamics with succession have been poorly examined (Huang et al., 2013; Jiao et al., 2013; Jiang et al., 2017). Therefore, it is essential to 
Biogeosciences Discuss., https://doi.org/10.5194/bg-2017-408

Manuscript under review for journal Biogeosciences

Discussion started: 23 October 2017

(c) Author(s) 2017. CC BY 4.0 License.

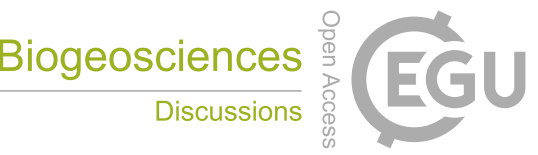

(c) (i)

characterize the dynamics of soil $\mathrm{C}, \mathrm{N}$, and $\mathrm{P}$ and nutrient stoichiometry following succession of secondary forests in southern China.

In this study, we investigated the concentrations and storage of SOC, TN, and TP at depths of $0-10,10-20$, and $20-30 \mathrm{~cm}$ in subtropical forests in their early, middle, and late succession stages in southern China. Specifically, the objectives were: (1) to examine changes in SOC, TN, and TP concentration and storage patterns along secondary forest succession; (2) to reveal soil C, N, and P stoichiometry characteristics and nutrient limitation in secondary forests; and (3) to investigate the effects of stand characteristics, soil properties, and topography variables on SOC, TN, and TP concentrations and their storage in a subtropical forest.

\section{Materials and methods}

\subsection{Study site description}

The study site was located in the Dashanchong Forest Park (latitude $28^{\circ} 23^{\prime} 58^{\prime \prime} \mathrm{N}-28^{\circ} 24^{\prime} 58^{\prime \prime} \mathrm{N}$, longitude $113^{\circ} 17^{\prime} 46^{\prime \prime}$ E-113 $13^{\circ}$ 08" E), Changsha County, Hunan Province, China. The park is characterized by hilly topography, with an elevation ranging from $55 \mathrm{~m}$ to $260 \mathrm{~m}$ above mean sea level. The site resides within the central region of the humid mid-subtropical monsoon zone in China. Based on climate data obtained from 1954 to 2010, the mean annual air temperature is $17.3^{\circ} \mathrm{C}$, and maximum and minimum temperatures are $39.8^{\circ} \mathrm{C}$ and $-10.3^{\circ} \mathrm{C}$, respectively. The mean annual precipitation is $1416.4 \mathrm{~mm}$, and fluctuates between $936.4 \mathrm{~mm}$ and $1954.2 \mathrm{~mm}$. The well-drained clay loam red soil developed from slate and shale parent rock, and is classified as a Alliti-Udic Ferrosol, corresponding to Acrisol in the World Reference Base for Soil Resource (IUSS Working Group WRB, 2006). The subtropical evergreen broadleaved forest is the climax vegetation of the region. Due to historical human disturbances, the forest park has a range of secondary forests at different succession stages (Ouyang et al., 2016).

\subsection{Experiment design and soil sampling}

Three secondary forests, representing different succession stages, were chosen in this study. (1) The early stage is a Pinus massoniana - Lithocarpus glaber forest (PM-LG) dominated by shade-intolerant coniferous species. (2) The middle stage is 
Biogeosciences Discuss., https://doi.org/10.5194/bg-2017-408

Manuscript under review for journal Biogeosciences

Discussion started: 23 October 2017

(c) Author(s) 2017. CC BY 4.0 License.

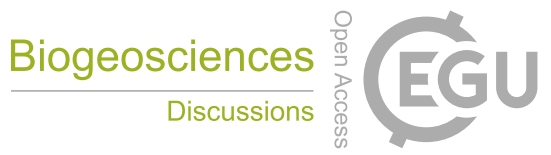

(c) (i)

a Choerospondias axillaris forest (CA) dominated by shade-intolerant deciduous broadleaf species. (3) The later stage is a $L$. glaber - Cyclobalanopsis glauca forest (LG-CG) dominated by shade-tolerant evergreen broadleaved species. A 1-ha permanent plot was established within each forest. Detailed stand characteristics of the three forests were described in our previous study (Ouyang et al., 2016).

Each 1-ha plot was divided into $10010 \times 10 \mathrm{~m}$ subplots. Within each subplot, soil samples were collected at depths of $0-10$, 10-20, and $20-30 \mathrm{~cm}$ and taken to a laboratory to measure SOC, TN, and TP concentrations and $\mathrm{pH}$ values. Soil bulk density for each depth was measured in triplicate using a steel soil corer, $5.0 \mathrm{~cm}$ in diameter and $5.0 \mathrm{~cm}$ in length, at points adjacent to the soil sampling plots. Thus, one pit was dug to $30 \mathrm{~cm}$ depth at the center of a subplot and three soil samples were taken. The volume of each soil corer and soil dry mass, after oven-drying at $105^{\circ} \mathrm{C}$ for $48 \mathrm{~h}$, were measured.

\subsection{Physical and chemical analysis}

Soil $\mathrm{pH}$ values were measured at a soil-to-water (deionized) ratio of 1:2.5 using an FE20 pH meter (Mettler Toledo, Shanghai, China). Soil texture, i.e., clay, silt, and sand contents, were determined using the pipette method (Gee and Bauder, 1986). Soil moisture contents were measured gravimetrically and expressed as percentages of soil water to dry soil weight. For SOC, TN, and TP, soils were manually sorted to visually remove stones, plant roots, and litter, and then sieved through a

$2 \mathrm{~mm}$ mesh. SOC concentrations were determined using the $\mathrm{K}_{2} \mathrm{Cr}_{2} \mathrm{O}_{7} / \mathrm{H}_{2} \mathrm{SO}_{4}$ oxidation method. TN concentrations were measured using a Semimicro-Kjeldahl method, and TP concentrations were measured by sodium hydroxide $(\mathrm{NaOH})$ fusion and the Mo-Sb colorimetric method.

\subsection{Calculation of SOC, TN, and TP storage}

For each individual soil profile, the mass storage per area $\left(\mathrm{Mg} \mathrm{ha}^{-1}\right)$ for $\mathrm{SOC}\left(\mathrm{C}_{\mathrm{S}}\right)$, TN $\left(\mathrm{N}_{\mathrm{S}}\right)$, and TP $\left(\mathrm{P}_{\mathrm{S}}\right)$ was calculated using the following equations (Liu et al., 2011):

$$
C_{s}=\sum_{i}^{n}\left[D_{i} \times S O C_{i} \times B D_{i} \times\left(1-G_{i}\right) / 100\right] / 100
$$


Biogeosciences Discuss., https://doi.org/10.5194/bg-2017-408

Manuscript under review for journal Biogeosciences

Discussion started: 23 October 2017

(c) Author(s) 2017. CC BY 4.0 License.

$$
\begin{aligned}
& N_{s}=\sum_{i}^{n}\left[D_{i} \times T N_{i} \times B D_{i} \times\left(1-G_{i}\right) / 100\right] / 100 \\
& P_{s}=\sum_{i}^{n}\left[D_{i} \times T P_{i} \times B D_{i} \times\left(1-G_{i}\right) / 100\right] / 100
\end{aligned}
$$

where $n$ is the number of soil layers; $i$ is the $i$ th soil layer; $S O C_{i}, T N_{i}$, and $T P_{i}$ are the $\mathrm{SOC}, \mathrm{TN}$, and TP concentrations $\left(\mathrm{g} \mathrm{kg}^{-1}\right)$ in the $i$ th soil layer, respectively; and $B D_{i}, G_{i}$, and $\mathrm{D}_{\mathrm{i}}$ are soil bulk density $\left(\mathrm{g} \mathrm{cm}^{-3}\right)$, the proportion (\%) of coarse $(>2 \mathrm{~mm})$

fragments, and the thickness $(\mathrm{cm})$ in the $i$ th layer, respectively. In this study, we calculated $\mathrm{C}_{\mathrm{S}}, \mathrm{N}_{\mathrm{S}}$, and $\mathrm{P}_{\mathrm{S}}$ for a depth of 30 cm using data from the three different soil layers $(0-10,10-20$, and $20-30 \mathrm{~cm})$.

\subsection{Statistical analyses}

Differences in SOC, TN, and TP concentrations, storage, and their ratios in the forests at a given soil depth were analyzed using one-way analysis of variance (ANOVA), followed by Tukey's test. The effects of forest and soil depth on SOC, TN, and TP concentrations, storage, and their ratios were tested using two-way analysis of variance (ANOVA). Multivariate models were used to explain SOC, TN, and TP concentrations and their storage with three types of variables: (1) stand factors, including Shannon index, tree species number, stand density, average stand DBH, evergreen proportion (E), deciduous proportion (D), and litter biomass; (2) soil properties, including soil $\mathrm{pH}$ value, soil bulk density (BD), soil moisture concentrations (MC), clay content, and silt content and (3) topography variables, including elevation and convexity. All statistical analyses were performed using R 3.00 (R Development Core Team, 2012).

\section{Results}

\subsection{Changes in SOC, TN, and TP concentrations with succession}

Forest, soil depth and their interaction significantly affected SOC, TN, and TP concentrations (Table 2). SOC and TN concentrations at all soil depths increased with forest succession (Fig. 1A and Fig. 1B). Mean SOC for 0-30 cm soil depth increased from $12.61 \mathrm{~g} \mathrm{~kg}^{-1}$ in the PM-LG forest to $18.61 \mathrm{~g} \mathrm{~kg}^{-1}$ in the $\mathrm{LG}-\mathrm{CG}$ forest, and mean TN increased from $1.22 \mathrm{~g}$ $\mathrm{kg}^{-1}$ in the PM-LG forest to $1.63 \mathrm{~g} \mathrm{~kg}^{-1}$ in the LG-CG forest. In a given forest, SOC and TN concentrations decreased with 
Biogeosciences Discuss., https://doi.org/10.5194/bg-2017-408

Manuscript under review for journal Biogeosciences

Discussion started: 23 October 2017

(c) Author(s) 2017. CC BY 4.0 License.

soil depth, with the highest value at a depth of $0-10 \mathrm{~cm}$.

In contrast, TP concentrations at all soil depths decreased with forest succession (Fig. 1C). Mean TP concentrations for 0-30 cm depth decreased from $0.31 \mathrm{~g} \mathrm{~kg}^{-1}$ in the PM-LG forest to $0.25 \mathrm{~g} \mathrm{~kg}^{-1}$ in the $\mathrm{LG}-\mathrm{CG}$ forest. No significant difference was found for TP concentrations between the $\mathrm{CA}$ and LG-CG forests. Along with succession, there was a pronounced decrease in TP concentrations at a soil depth of $0-10 \mathrm{~cm}$ (Fig. 1C). As soil depth increased, TP concentrations appeared to decrease.

\subsection{Changes in SOC, TN, and TP storage with succession}

Forest succession, soil depth, and their interaction significantly affected $\mathrm{C}_{S}, \mathrm{~N}_{\mathrm{S}}$ and $\mathrm{P}_{\mathrm{S}}($ Table 1$)$. $\mathrm{C}_{\mathrm{S}}$ and $\mathrm{N}_{\mathrm{S}}$ for three soil depths increased with forest succession (Fig. 2A and Fig. 2B). Mean $\mathrm{C}_{\mathrm{S}}$ for $0-30 \mathrm{~cm}$ depth increased from $45.95 \mathrm{Mg}^{-1}$ in the PM-LG forest to $62.46 \mathrm{Mg} \mathrm{ha}^{-1}$ in the $\mathrm{LG}-\mathrm{CG}$ forest, and mean $\mathrm{N}_{\mathrm{S}}$ increased from $4.49 \mathrm{Mg}^{-1}$ in the PM-LG forest to

$5.44 \mathrm{Mg} \mathrm{ha}^{-1}$ in the $\mathrm{LG}-\mathrm{CG}$ forest. In a given forest, $\mathrm{C}_{\mathrm{S}}$ and $\mathrm{N}_{\mathrm{S}}$ decreased with soil depth, with the highest value at a soil depth of $0-10 \mathrm{~cm}$.

Similar to TP concentrations, TP storage at all soil depths decreased with forest succession (Fig. 2C). Mean PS for 0-30 cm soil depth decreased from $1.11 \mathrm{Mg} \mathrm{ha}^{-1}$ in the PM-LG forest to $0.87 \mathrm{Mg} \mathrm{ha}^{-1}$ in the LG-CG forest, although no significant differences in $\mathrm{P}_{\mathrm{S}}$ values were found between the CA and LG-CG forests. The highest $\mathrm{P}_{\mathrm{S}}$ was in the topsoil (0-10 cm), and the lowest was in the $20-30 \mathrm{~cm}$ soil layer (Fig. 2C).

\subsection{Variations in soil $C: N, C: P$, and $N: P$ ratios with succession}

Soil $\mathrm{C}: \mathrm{N}, \mathrm{C}: \mathrm{P}$, and N:P ratios were significantly affected by forest succession and soil depth. While interactions between forest succession and soil depth significantly affected C:P and N:P ratios, they did not significantly affect C:N ratios (Table 1).

Soil $\mathrm{C}: \mathrm{N}$ ratios at all three depths increased with forest succession. Furthermore, $\mathrm{C}: \mathrm{N}$ ratios in the LG-CG and $\mathrm{CA}$ forests were significantly higher than those in the PM-LG forest $(P<0.05)$ (Fig. 3A) for all soil depths. C:N ratios did not significantly differ between the LG-CG and CA forests at the three depths $(P>0.05)$. In all forests, the soil C:N ratios in the 0-10 cm soils were significantly higher than at depths of 10-20 and 20-30 cm (Fig. 3B). 
Biogeosciences Discuss., https://doi.org/10.5194/bg-2017-408

Manuscript under review for journal Biogeosciences

Discussion started: 23 October 2017

(c) Author(s) 2017. CC BY 4.0 License.

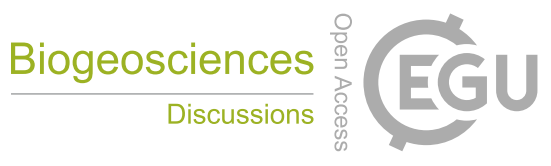

(c) (i)

Soil C:P and N:P ratios increased with forest succession and differed significantly between forests. Soil C:P and N:P ratios at depths of $0-10$ and $10-20 \mathrm{~cm}$ in the LG-CG forest were significantly higher than those of the CA and PM-LG forests $(P<$ 0.05). However, at 20-30 cm depth, soil C:P and N:P ratios in the CA forest were significantly higher than those in the LG-CG and CA forests $(P<0.05)$ (Fig. 3B and 3C). In all forests, soil C:P ratios were higher at $0-10 \mathrm{~cm}$ depth than at lower soil layers. Soil C:P and N:P ratios did not significantly differ between $0-10 \mathrm{~cm}$ and $20-30 \mathrm{~cm}$ depths in the LG-CG and CA forests $(P>0.05)$. However, there were significant differences between the three soil depths in the LG-CG forest (Fig. 3B and $3 \mathrm{C})$.

In the PM-LG and CA forests, the soil C:N:P ratios gradually decreased at soil depths of $0-10 \mathrm{~cm}$ and $10-20 \mathrm{~cm}$, then increased at a soil depth of $20-30 \mathrm{~cm}$. In the LG-CG forest, the C:N:P gradually decreased from the $0-10$ to $20-30 \mathrm{~cm}$ depths (Table 2).

\subsection{Factors affecting SOC, TN, and TP concentrations and their storage}

Stem density, litter biomass, soil PH, bulk density, silt content, and elevation showed significant effects on both SOC concentrations and storage, while other variables were not significant (Table 4 and Table 5). The TN concentration and storage multivariate model indicated that stem density, litter biomass, soil PH, bulk density, silt content, and elevation had significant effects on both SOC concentrations and storage. Only the Shannon index significantly affected TN concentrations, while other predictors did not (Table 4 and Table 5). In comparison, the TP concentration and storage multivariate model indicated that the Shannon index, stem density, litter biomass, soil PH, bulk density, silt content, and clay content had a significant effect on both SOC concentrations and storage. Elevation and convexity significantly affected TP storage, while other variables did not (Table 4 and Table 5).

\section{Discussion}

\subsection{Effects of forest types and soil depth on SOC, STN, and STP concentrations and storage}

Plant species influence soil $\mathrm{C}, \mathrm{N}$, and P primarily through litter decomposition, root secretion, soil mineralization, and 
Biogeosciences Discuss., https://doi.org/10.5194/bg-2017-408

Manuscript under review for journal Biogeosciences

Discussion started: 23 October 2017

(c) Author(s) 2017. CC BY 4.0 License.

contributions from soil fauna, insects, and microorganisms (Gao et al., 2014). Furthermore, plant species differ in their capacity to utilize and capture C, N, and P (Wang et al., 2013). In this study, forest, soil depth, and their interactions significantly affected the SOC, TN, and TP concentrations and storage (Table 2), indicating that forest types and soil depth were important factors affecting the soil nutrient distribution. A similar change trend between concentrations and storage was found for SOC, TN, and TP (Fig. 1 and Fig. 2).

Along the successional gradient, we found SOC and TN concentrations increased, but TP decreased. This result indicated that forest succession enhanced SOC and TN concentrations and storage (Fig. 1), in agreement with studies that found that vegetation succession increased SOC and TN concentrations and storage (Davis et al., 2007; Deng et al., 2013; 2014). This general trend is likely due to vegetation recovery facilitating SOC and TN accumulation from litter and root input to the soil (Tang et al., 2010; Deng et al., 2013). For instance, some research has indicated that late successional species stands produce more fine roots than those at earlier succession stages (Yang et al., 2010; Deng et al., 2014). Total standing fine root biomass and annual fine root production increased between an early successional stage PM-LG forest to a late successional stage LG-CG forest, and their turnover (dead roots) also increased with vegetation succession (Liu et al., 2014).

In contrast, TP concentrations declined along forest succession due to the demands of vegetation growth. $\mathrm{P}$ is derived primarily from rock weathering, leading to extremely P-deficient soils (Aerts and Chapin, 1999). P is also the primary limiting factor in red soil areas in southern China due to P absorption and sorption (Gao et al., 2014). Our results support the conclusion that $\mathrm{P}$ becomes increasingly limiting relative to $\mathrm{N}$ in forests over time (Walker et al., 1976; Wardle et al., 2004).

Soil depth significantly affected SOC and TN concentrations and storage in the present study (Table 1). SOC and TN had significantly different dynamics between topsoil and subsoil in all forests (Fig. 2). SOC and TN concentrations in the upper soil $(0-10 \mathrm{~cm})$ for all forests were significantly higher than that in lower soil. This result agrees with previous studies showing that surface soil more actively sequesters SOC and TN (Wu, 2004; Justine et al., 2017). Most natural biological processes in forest ecosystems occur on the soil surface, which results in the highest SOC and TN in the topsoil (Hooper et al., 2000; Tian et al., 2010; Justine et al., 2017). Unlike TN and SOC, there were no significant differences in TP between the upper soil $(0-10 \mathrm{~cm})$ and the subsoil $(10-20 \mathrm{~cm})$ layers in all forests, and especially for the LG-CG forest (Fig. 2). This observation suggests that TP remained relatively stable during the late succession stage. One possible explanation is that TP 
Biogeosciences Discuss., https://doi.org/10.5194/bg-2017-408

Manuscript under review for journal Biogeosciences

Discussion started: 23 October 2017

(c) Author(s) 2017. CC BY 4.0 License.

is primarily derived from rock $\mathrm{P}$, so $\mathrm{P}$ available to plants in the soil is extremely low in forested soils, and depends on interactions with iron (Fe) and aluminum (Al) (Oelmann et al., 2011; Gao et al., 2014).

\subsection{Effects of forest types and soil depth on C:N, C:P, and N:P ratios}

In this study, soil C:N, C:P, and N:P ratios were significantly affected by forest succession, soil depths, and their interactions

(Table 1). Forest succession improved soil C:N, C:P, and N:P ratios The largest soil C:N, C:P, and N:P ratios of 11.81, 70.95, and 6.25, respectively (Fig. 4A, 4B and 4C), were found in the $0-30 \mathrm{~cm}$ soil in the late successional stage LG-CG forest. Previous studies showed that varying land use types have different soil C:N:P ratios (Li et al., 2012; Zhao et al., 2015). Li et al. (2012) suggested that variations in soil CNP stoichiometry might result from different vegetation and land management practices. Zhao et al. (2015) conjectured that only vegetation and plant communities affect soil nutrient stoichiometry. Fan et al. (2015) demonstrated that soil depth and successional stage significantly influence soil CNP stoichiometry.

Generally, living organisms and soil have relatively stable C:N:P ratios (Zhao et al., 2015). Furthermore, key ecosystem characteristics are determined by these ratios (Michaels et al., 2003). Globally, a well-balanced C:N:P ratio is 186:13:1 for surface soil, i.e., 0-10 cm (Cleveland and Liptzin, 2007; Wang et al., 2014). A general C:N:P ratio is 134:9:1 for 0-10 cm organic-rich soil and 60:5:1 for the entire soil depth $(0-250 \mathrm{~cm})$ in China (Tian et al., 2010). In this study, the mean C:N:P ratio was 59.7:5.4:1 for the $0-30 \mathrm{~cm}$ depth, and the highest $\mathrm{C}: \mathrm{N}: \mathrm{P}(69.2: 5.7: 1)$ was found for the $0-10 \mathrm{~cm}$ depth (Table 3). These ratios were far below the average C:N:P for China and globally. For $0-10 \mathrm{~cm}$ depth soils, the C:N, C:P, and N:P ratios of $12.25,69.25$, and 5.69, respectively, were lower than the average Chinese values reported in Tian et al. (2010), which were 14.4, 136, and 9.3, respectively. These differences might be due to soil samples containing humified litter in the Cleveland and Liptzin (2007) and Tian et al. (2010) studies, resulting in relatively higher C:N, C:P and N:P ratios than in our results.

C:N ratios in our study were nearly all $>10$ in all forests and soil layers (Fig. 4A). A low C:N ratio $(<25)$ implies that soil organic matter is accumulating slower than it is decomposing (Zhao et al., 2015) and that there is net mineralization of $\mathrm{N}$ in the soil (Wei et al., 2009). A C:N ratio lower than 10 indicates that less organic matter is being merged into the soil (Saikh et al., 1998; Yimer et al., 2007). Similar to Li et al. (2016), we found TP changed only slightly between forests succession types 
Biogeosciences Discuss., https://doi.org/10.5194/bg-2017-408

Manuscript under review for journal Biogeosciences

Discussion started: 23 October 2017

(c) Author(s) 2017. CC BY 4.0 License.

and soil depth; the soil C:P and N:P ratios were determined by the SOC and TN concentrations. The LG-CG (late succession) and CA (middle succession) forests had higher SOC and TN concentrations than the PM-LG (early succession) forest, resulting in higher $\mathrm{C}: \mathrm{P}$ and $\mathrm{N}: \mathrm{P}$ ratios, which is in agreement with the global soil nutrient ratios reported by $\mathrm{Cleveland}$ and Liptzin (2007). In addition, the topsoil layer $0-10 \mathrm{~cm}$ had greater soil $\mathrm{C}: \mathrm{N}, \mathrm{C}: \mathrm{P}$, and N:P ratios than the subsoil or deeper soil because the litter layer released more nutrients into the topsoil ( $\mathrm{Li}$ et al., 2016). The soil C:P ratios ranged from 42.91 to 70.95 for the $0-30 \mathrm{~cm}$ soil depth in this study, which implied a net mineralization of soil nutrients $(<200)$ (Pau, 2007). Although the total soil N:P ratios did not exceed the Redfield ratio of 16, the threshold postulated for P limitation in plankton (Jia, 2013), all N:P ratios in fresh leaves in all forests were greater than 16 and P concentrations were $<1.0 \mathrm{mg} \mathrm{g}^{-1}$, indicating P limitation (Zeng et al., 2017).

10 Our study supported the hypothesis that C:N:P Redfield-like ratios are common in forest soil (Cleveland and Liptzin, 2007). The SOC, TN, and TP concentrations were significantly correlated (Table 3), and the relatively high correlation coefficient (0.83) for $\mathrm{C}$ and $\mathrm{N}$ concentrations indicated that the C:N ratio was highly constrained. Relatively constrained C:P and N:P ratios were also observed based on the correlation coefficients of 0.26 for the $\mathrm{C}$ and $\mathrm{P}$ concentrations, 0.30 for the $\mathrm{N}$ and $\mathrm{P}$ concentrations. Together, these implied a relatively constrained C:N:P ratio in subtropical forest soil, which is similar to that reported in Cleveland and Liptzin (2007) and Tian et al (2010).

\subsection{Factors affecting SOC, TN, and TP concentrations and their storage}

SOC and soil nutrient concentrations and their storage usually vary depending on stand characteristics, soil properties, e.g., bulk density, texture, moisture, and pH value, and topography (Xia et al., 2016; Jiang et al., 2017). We found stand density, litter biomass, soil bulk density, $\mathrm{pH}$, texture, and altitude did significantly affect SOC, TN, and TP concentrations and their storage (Table 4 and Tables 5). In our previous study, we found stand density has a significant effect on stand biomass in this

study area (Ouyang et al., 2016), which could create variations in SOC, TN, and TP concentrations and their storage. In natural succession, more plant litter decomposes and is then transformed into soil organic matter fallowing vegetation recovery and additional accumulation of plant litters (Zhao et al., 2010). Soil texture, pH, and soil moisture also contribute to variations in SOC, N, and P concentrations and their storage (Liu et al. 2015; Jiang et al., 2017). Soil bulk density 
Biogeosciences Discuss., https://doi.org/10.5194/bg-2017-408

Manuscript under review for journal Biogeosciences

Discussion started: 23 October 2017

(c) Author(s) 2017. CC BY 4.0 License.

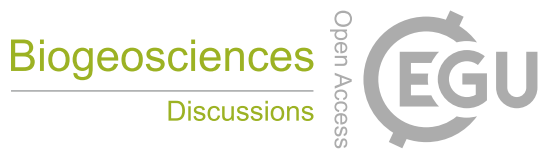

(c) (i)

measurements were significantly related to SOC, TN, and TP concentrations and their storage. This correlation is consistent with those previous reported in Liao et al. (2012) and Deng et al. (2013). The relatively higher SOC and TN concentrations in clayey soils may be due to more decomposed organic matter and stabilization of clay particles in the soils (Leifeld et al., 2005; Puget and Lal, 2005). Liu et al. (2015) found that soil texture was a key factor affecting variations in SOC and soil nutrients under Karst topography. Yuan et al. (2013) found that soil moisture and $\mathrm{pH}$ value could explain 51\% of observed SOC variability in a temperate forest. Soil $\mathrm{pH}$ can affect the biogeochemical cycles of SOC and other nutrients by changing microbial community activity, leading to variations in C, N, and P concentrations in forest soil (Cleveland and Liptzin, 2007; Deng et al., 2013). However, no significant relationships were observed between soil moisture and SOC and TN concentrations in our study. This agrees with the conclusions of Deng et al. (2013), who also found no significant relationships between soil moisture and SOC during vegetation succession for humid climate conditions with annual rainfall above $600 \mathrm{~m}$ in China. It is well known that topography, e.g., elevation and convexity, can affect local microclimates, litter decomposition, and leaching of soil surface nutrients, resulting in large variations in SOC and soil nutrients (Xia et al., 2016; Jiang et al., 2017). This relationship is especially clear in our study site under mountainous conditions, where topographic gradients are variable (Yuan et al. 2013; Xia et al., 2016).

\section{Conclusions}

Our results support the hypothesis that forest succession significantly affects SOC, TN, and TP concentrations, storage, and stoichiometry. Forest succession improved SOC and TN concentrations and storage, but decreased TP concentrations and storage. In addition to forest succession, stand density, litter, soil properties, e.g., soil bulk density, pH, and texture, and typography could significant affect SOC, TN, and TP concentrations and storage. Moreover, soil C:P and N:P ratios significantly increased far more than N:P ratios with succession, indicating an increasing P limitation for plant growth as succession proceeded in this region. These results enrich our current knowledge of $\mathrm{C}, \mathrm{N}$, and P soil stoichiometry in global forest ecosystems, and provide useful information for sustainable forest management in southern China. 
Biogeosciences Discuss., https://doi.org/10.5194/bg-2017-408

Manuscript under review for journal Biogeosciences

Discussion started: 23 October 2017

(c) Author(s) 2017. CC BY 4.0 License.

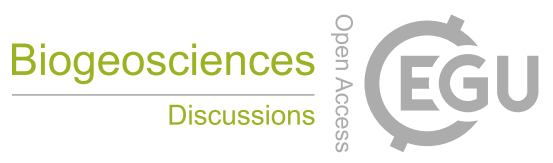

(c) (i)

\section{Acknowledgements}

This work was supported by the National Key Research and Development Program of China (2016YFD0600202), National Natural Science Foundation of China (31570447 and 31700636), China Postdoctoral Science Foundation (2017M612605), and Huitong Forest Ecological Station Program funded by the State Forestry Administration of China. We would also like to thank the administrative staff from the Dashanchong Forest Farm for their local support of this study.

\section{References}

Aerts, R., and Chapin, F. S.: The mineral nutrition of wild plants revisited: a re-evaluation of processes and patterns, Adv. Ecol. Res, 30, 1-67, 1999.

10 Andrews, S.S, Karlen, D.L, and Cambardella, C.A.: The soil management assessment framework: a quantitative soil quality evaluation method, Soil. Sci. Soc. Amer. J., 68, 1945-196, 2004.

Bond-Lamberty, B., Gower, S.T., Wang, C., Cyr, P., and Veldhuis, H.: Nitrogen dynamics of a boreal black spruce wildfire chronosequence, Biogeochemistry, 1, 1-16, 2006.

Chang, R.Y., Fu, B.J., Liu, G.H., and Liu, S.G.: Soil carbon sequestration potential for "Grain for Green” project in Loess Plateau, China, Environ. Manage., 48, 1158-1172, 2011.

Chapin, F.S.: Effects of plant traits on ecosystem and regional processes: a conceptual framework for predicting the consequences of global change, Ann. Bot., 91, 455-463, 2003.

Chen, C.R., Condron, L.M., Davis, M.R, and Sherlock, R.R.: Effects of afforestation on phosphorus dynamics and biological properties in a New Zealand grassland soil, Plant Soil, 220, 151-163, 2000. 
Biogeosciences Discuss., https://doi.org/10.5194/bg-2017-408

Manuscript under review for journal Biogeosciences

Discussion started: 23 October 2017

(c) Author(s) 2017. CC BY 4.0 License.

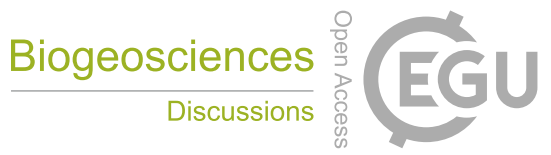

(c) (i)

Biogeochemistry, 85, 235-252, 2007.

Davis, M., Nordmeyer, A., Henley, D., and Watt, M.: Ecosystem carbon accretion 10 years after afforestation of depleted subhumid grassland planted with three densities of Pinus nigra, Global. Change. Biol., 13, 1414-1422, 2007.

Deng, L., Wang, K.B., Chen, M.L., Shangguan, Z.P., and Sweeney, S.: Soil organic carbon storage capacity positively related to forest succession on the Loess Plateau, China, Catena, 110, 1-7, 2013.

Deng, L., Wang, K.B., and Shangguan, Z.P.: Long-term natural succession improves nitrogen storage capacity of soil on the Loess Plateau, China, Soil. Res., 52, 262-270, 2014.

Fan, H., Wu, J., Liu, W., Yuan, Y., Hu, L., and Cai, Q.: Linkages of plant and soil C: N: P stoichiometry and their relationships to forest growth in subtropical plantations, Plant Soil, 392, 127-138, 2015.

Gao, Y., He, N.P., Yu, G.R., Chen, W.L., and Wang, Q.F.: Long-term effects of different land use types on C, N, and P stoichiometry and storage in subtropical ecosystems: A case study in China, Ecol. Eng., 67, 171-181, 2014.

Gee, G.W., and Bauder, J.W.: Particle size analysis. In: Klute, A. (Ed.), Methods of Soil Analysis: Part I. Second edition. Agronomy Monograph, vol. 9. ASA and SSSA, Madison, WI, USA, pp. 383-411, 1986.

Hooper, D.U., Bignell, D.E., and Brown, V.K.: Interactions between aboveground and belowground biodiversity in terrestrial ecosystems: patterns, mechanisms and feedbacks, Bioscience, 50, 1049-1061, 2000.

Huang, W., Liu, J., Wang, Y., Zhou, G., Han, T., and Li, Y.: Increasing phosphorus limitation along three successional forests in southern China, Plant Soil, 364, 181-191, 2013.

IPCC (Intergovernmental Panel on Climate Change), Fourth Assessment Report, Climate Change 2007: Synthesis Report. Cambridge University Press, Cambridge, UK, 2007. 
Biogeosciences Discuss., https://doi.org/10.5194/bg-2017-408

Manuscript under review for journal Biogeosciences

Discussion started: 23 October 2017

(c) Author(s) 2017. CC BY 4.0 License.

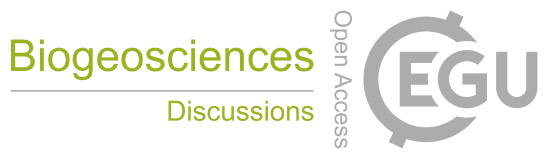

(c) (i)

IUSS Working Group.: World Reference Base for Soil Resources 2006. World Soil Resources Reports No. 103. FAO, Rome.

ISBN 92-5-105511-4, 2006.

Jia, X.X., Wei, X.R., Shao, M.A., and Li, X.Z.: Distribution of soil carbon and nitrogen along a revegetational succession on the Loess Plateau of China, Catena, 95, 160-168, 2012.

Jiao, F., Wen, Z.M., An, S.S., and Yuan, Z.: Successional changes in soil stoichiometry after land abandonment in Loess Plateau, China, Ecol. Eng., 58, 249-254, 2013.

Jiang, F., Wu, X., Xiang, W.H., Fang, X., Zeng, Y.L., Ouyang, S., Lei, P.F., Deng, X.W., Peng, C.H.: Spatial variations in soil organic carbon, nitrogen and phosphorus concentrations related to stand characteristics in subtropical areas, Plant Soil, 413, 289-301, 2017.

Jiménez, J.J., Lorenz, K., and Lal, R.: Organic carbon and nitrogen in soil particle-size under dry tropical forests from Guanacaste, Costa Rica - implications for within site soil organic stabilization, Catena, 86, 178-191, 2011.

Justine, M. F., Yang, W., Wu, F., Tan, B., Naeem Khan, M., and Li, Z.: Dissolved organic matter in soils varies across a chronosequence of Pinus massoniana plantations, Ecosphere, 8, 1-11, 2017.

Lal, R.: Soil carbon sequestration impacts on global climate change and food security, Science, 304, 1623-1627, 2004.

Leifeld, J., Bassin, S., and Fuhrer, J.: Carbon stocks in Swiss agricultural soils predicted by land-use, soil characteristics, and altitude, Agr. Ecosyst. Environ., 105, 255-266, 2005.

Li, C., Zhao, L., Sun, P., Zhao, F., Kang, D., Yang, G., Han, X., Feng, Y., and Ren, G.: Deep Soil C, N, and P storage and stoichiometry in response to land use patterns in the Loess Hilly Region of China, PLoS ONE, 11, e015907, 2016.

Li, Y., Wu, J., Liu, S., Shen, J., Huang, D., Su, Y., and Syers, J.K.: Is the C: N: P stoichiometry in soil and soil microbial 
Biogeosciences Discuss., https://doi.org/10.5194/bg-2017-408

Manuscript under review for journal Biogeosciences

Discussion started: 23 October 2017

(c) Author(s) 2017. CC BY 4.0 License.

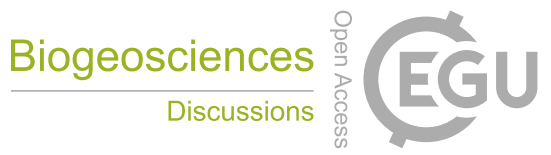

(c) (i)

biomass related to the landscape and land use in southern subtropical China? Global. Biogeochem. Cy., 26(GB4002),

2012.

Liao, C., Luo, Y., Fang, C., Chen, J., and Li, B.: The effects of plantation practice on soil properties based on the comparison between natural and planted forests: a meta-analysis, Global. Ecol. Biogeogr., 21, 318-327, 2012.

Liu, C., Xiang, W.H, Lei, P.F., Deng, X.W., Tian, D.L., Fang, X., and Peng, C.H.: Standing fine root mass and production in four Chinese subtropical forests along a succession and species diversity gradient, Plant Soil, 376, 445-459, 2014.

Liu, S.J., Zhang, W., Wang, K.L., Pan, F.J., Yang, S., and Shu, S.Y.: Factors controlling accumulation of soil organic carbon along vegetation succession in a typical karst region in Southwest China. Sci. Total. Environ., 521, 52-58, 2015.

Liu, Z.P., Shao, M.A., and Wang, Y.Q.: Effect of environmental factors on regional soil organic carbon storage across the Loess Plateau region, China, Agr. Ecosyst. Environ., 142, 184-194, 2011.

Liu, Z. P., Shao, M. A., and Wang, Y. Q.: Spatial patterns of soil total nitrogen and soil total phosphorus across the entire Loess Plateau region of China, Geoderma, 197, 67-78, 2013.

Mooshammer, M., Wanek, W., Hammerle, I., Fuchslueger, L., Hofhansl, F., Knoltsch, A., Schnecker, J., Takriti, M., Watzka, M., and Wild, B.: Adjustment of microbial nitrogen use efficiency to carbon: nitrogen imbalances regulates soil nitrogen cycling, Nat. Commun., 5, 2014.

Oelmann, Y., Richter, A.K., Roscher, C., Rosenkranz, S., Temperton, V.M., Weisser, W.W., and Wilcke, W.: Does plant diversity influence phosphorus cycling in experimental grasslands? Geoderma, 168, 178-187, 2011.

Ouyang, S., Xiang, W.H., Wang, X.P., Zeng, Y.L., Lei, P.F., Deng, X.W., and Peng, C.H.: Significant effects of biodiversity on forest biomass during the succession of subtropical forest in south China, For. Ecol. Manag., 372, 291-302, 2016. 
Biogeosciences Discuss., https://doi.org/10.5194/bg-2017-408

Manuscript under review for journal Biogeosciences

Discussion started: 23 October 2017

(c) Author(s) 2017. CC BY 4.0 License.

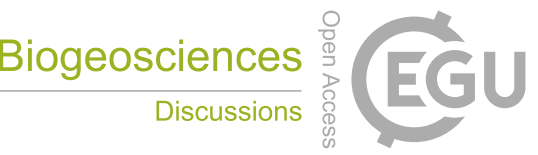

(c) (i)

Paul, E.A.: Soil Microbiology, Ecology, and Biochemistry, third ed. Academic Press, Amsterdam, 2007.

Puget, P., and Lal, R.: Soil organic carbon and nitrogen in a Mollisol in central Ohio as affected by tillage and land use, Soil.

Till. Res. 80, 201-213, 2005.

Quilchano, C., Marañón, T., Pérez-Ramos, I.M., Noejovich, L., Valladares, F., and Zavala, M.A.: Patterns and ecological

consequences of abiotic heterogeneity in managed cork oak forests of Southern Spain, Ecol. Res., 23, 127-139, 2008.

R Development Core Team: R: A Language and Environment for Statistical Computing. R Foundation for Statistical Computing, Vienna, Austria, 2012.

Saikh, H., Varadachari, C., and Ghosh, K.: Changes in carbon, nitrogen and phosphorus levels due to deforestation and cultivation: a case study in Simlipal National Park, India, Plant Soil, 198, 137-145,1998.

Sardans, J., and Penuelas, J.: The role of plants in the effects of global change on nutrient availability and stoichiometry in the plant-soil system, Plant. Physiol., 160, 1741-1761, 2012.

Tian, H., Chen, G., Zhang, C., Melillo, J.M., and Hall, C.A.S.: Pattern and variation of C: N: P ratios in China's soils: a synthesis of observational data, Biogeochemistry, 98, 139-151, 2010.

Walker, T. W., and Syers, J. K.: The fate of phosphorus during pedogenesis, Geoderma, 15, 1-19, 1976.

Wang, B., Liu, G.B., Xue, S., and Zhu, B.B.: Changes in soil physico-chemical and microbiological properties during natural succession on abandoned farmland in the Loess Plateau, Environ. Earth. Sci., 62, 91-925, 2011.

Wang, W., Sardans, J., Zeng, C., Zhong, C., Li, Y., and Peñuelas, J.: Responses of soil nutrient concentrations and stoichiometry to different human land uses in a subtropical tidal wetland, Geoderma, 232, 459-470, 2014.

Wang, X.L., Wang, Y.Q., and Wang, Y.J.: Use of exotic species during ecological succession can produce effects that 
Biogeosciences Discuss., https://doi.org/10.5194/bg-2017-408

Manuscript under review for journal Biogeosciences

Discussion started: 23 October 2017

(c) Author(s) 2017. CC BY 4.0 License.

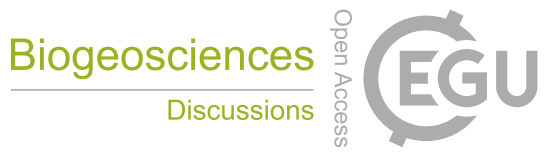

(c) (i)

resemble vegetation invasions and other unintended consequences, Ecol. Eng., 52, 247-251, 2013.

Wardle, D.A., Walker, L.R., and Bardgett, R.D.: Ecosystem properties and forest decline in contrasting long-term chronosequences. Science, 305, 509-513, 2004.

Wei, X., Shao, M., Fu, X., Horton, R., Li, Y., and Zhang, X.: Distribution of soil organic C, N and P in three adjacent land use patterns in the northern Loess Plateau, China, Biogeochemistry, 96, 149-162, 2009.

Wen, Z.M., Jiao, F., Liu, B.Y., Bu, Y.J., and Jiao, J.Y.: Natural vegetation succession and soil nutrient dynamics of abandoned farmlands in forest-steppe zone on Loess Plateau, China. J. Appl. Ecol., 16, 2025-2029, 2005.

Wu, J.G.: The mineralization of soil organic carbon under different land uses in the Liupan mountain forest zone. Chinese J. Plant. Ecol. 28, 530-538, 2004. (in Chinese with English abstract)

Xia, S.W., Chen, J., Schaefer, D., and Goodale, U. M.: Effect of topography and litterfall input on fine-scale patch consistency of soil chemical properties in a tropical rainforest. Plant Soil 404, 385-398, 2016.

Yang, L.Y., Wu, S.T., and Zhang, L.B.: Fine root biomass dynamics and carbon storage along a successional gradient in Changbai Mountains, China. Forestry 83, 379-387, 2010.

Yimer, F., Ledin, S., and Abdelkadir, A.: Changes in soil organic carbon and total nitrogen concentrations in three adjacent land use types in the Bale Mountains, south-eastern highlands of Ethiopia. For. Ecol. Manag. 242, 337-342, 2007.

Yuan, Z.Q., Gazol, A., Lin, F., Ye, J., Shi, S., Wang, X.G., and Hao, Z.Q.: Soil organic carbon in an old-growth temperate forest: spatial pattern, determinants and bias in its quantification. Geoderma 195, 48-55, 2013.

Zechmeister-Boltenstern, S., Keiblinger, K.M., Mooshammer, M., Penuelas, J., Richter, A., Sardans, J., and Wanek, W.: The application of ecological stoichiometry to plant-microbial-soil organic matter transformations. Ecol. Monogr. 85, 
Biogeosciences Discuss., https://doi.org/10.5194/bg-2017-408

Manuscript under review for journal Biogeosciences

Discussion started: 23 October 2017

(c) Author(s) 2017. CC BY 4.0 License.

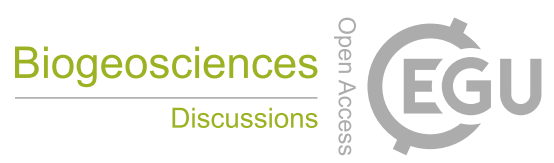

(c) (i)

$133-155,2015$.

Zeng, Y.L., Fang, X., Xiang, W.H., Deng, X.W., and Peng, C.H.: Stoichiometric and nutrient resorption characteristics of dominant tree species in subtropical Chinese forests. Ecol. Evol. (In pressing), 2017.

Zhao, F., Sun, J., Ren, C., Kang, D., Deng, J., Han, X., and Ren, G.: Land use change influences soil C, N, and P stoichiometry under 'Grain-to-Green Program' in China. Sci. Rep-UK, 5, 2015.

Zhao, S.W., Zhao, Y.G., and Wu, J.S.: Quantitative analysis of soil pores under natural vegetation successions on the Loess Plateau. Sci. China. Earth. Sci. 53, 617-625, 2010. 
Biogeosciences Discuss., https://doi.org/10.5194/bg-2017-408

Manuscript under review for journal Biogeosciences

Discussion started: 23 October 2017

(c) Author(s) 2017. CC BY 4.0 License.

Table 1 The effects of forest, soil depth, and stand $\times$ depth interaction on SOC, TN, and TP concentrations and storage, and $\mathrm{C}: \mathrm{N}, \mathrm{C}: \mathrm{P}$, and N:P ratios. $P$ values from two-way ANOVA tests are presented. Bold font indicates significant differences at $P<0.05$.

\begin{tabular}{cccccccccc}
\hline Factor & SOC & TN & TP & CS & NS & Ps & C:N & C:P & N:P \\
\hline Stand & $\mathbf{0 . 0 0 0 0}$ & $\mathbf{0 . 0 0 0 0}$ & $\mathbf{0 . 0 0 0 0}$ & $\mathbf{0 . 0 0 0 0}$ & $\mathbf{0 . 0 0 0 0}$ & $\mathbf{0 . 0 0 0 0}$ & $\mathbf{0 . 0 0 0 0}$ & $\mathbf{0 . 0 0 0 0}$ & $\mathbf{0 . 0 0 0 0}$ \\
Depth & $\mathbf{0 . 0 0 0 0}$ & $\mathbf{0 . 0 0 0 0}$ & $\mathbf{0 . 0 0 0 0}$ & $\mathbf{0 . 0 0 0 0}$ & $\mathbf{0 . 0 0 0 0}$ & $\mathbf{0 . 0 0 0 0}$ & $\mathbf{0 . 0 0 0 0}$ & $\mathbf{0 . 0 0 0 0}$ & $\mathbf{0 . 0 0 0 0}$ \\
Stand $\times$ depth & $\mathbf{0 . 0 0 2 6}$ & $\mathbf{0 . 0 4 2 1}$ & $\mathbf{0 . 0 3 2 4}$ & $\mathbf{0 . 0 0 0 0}$ & $\mathbf{0 . 0 0 0 0}$ & $\mathbf{0 . 0 0 0 0}$ & 0.0614 & $\mathbf{0 . 0 0 0 0}$ & $\mathbf{0 . 0 0 0 0}$ \\
\hline
\end{tabular}

SOC, TN, TP, Cs, Ns, Ps, C:N, C:P, N:P, BD, and MC denote soil organic carbon, soil total nitrogen, soil total phosphorus, storage of soil organic carbon, storage of soil total nitrogen, storage of soil total phosphorus, C:N ratio, C:P ratio, N:P ratio, soil bulk density, and soil moisture concentrations, respectively. 
Biogeosciences Discuss., https://doi.org/10.5194/bg-2017-408

Manuscript under review for journal Biogeosciences

Discussion started: 23 October 2017

(c) Author(s) 2017. CC BY 4.0 License.

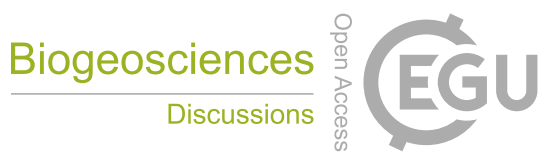

(c) (1)

Table 2 Stoichiometry of soil C:N:P in three forest types in southern China.

\begin{tabular}{ccccc}
\hline \multirow{2}{*}{ Soil depth $(\mathrm{cm})$} & \multicolumn{4}{c}{ C:N:P of different forest types } \\
\cline { 2 - 4 } & Early (PM-LG) & Middle (CA) & Late (LG-CG) & Average \\
\hline $0-10$ & $47.5: 4.3: 1$ & $70.7: 5.7: 1$ & $89.3: 7.0: 1$ & $69.2: 5.7: 1$ \\
$10-20$ & $36.7: 3.8: 1$ & $59.4: 5.4: 1$ & $65.7: 6.3: 1$ & $53.9: 5.2: 1$ \\
$20-30$ & $44.4: 4.5: 1$ & $65.5: 6.1: 1$ & $57.8: 5.4: 1$ & $55.9: 5.3: 1$ \\
Mean & $42.9: 4.2: 1$ & $65.2: 5.7: 1$ & $70.9: 6.2: 1$ & $59.7: 5.4: 1$ \\
\hline
\end{tabular}

PM-LG, Pinus massoniana - Lithocarpus glaber forest; CA, Choerospondias axillaris forest; LG-CG, L. glaber Cyclobalanopsis glauca forest. 
Biogeosciences Discuss., https://doi.org/10.5194/bg-2017-408

Manuscript under review for journal Biogeosciences

Discussion started: 23 October 2017

(c) Author(s) 2017. CC BY 4.0 License.

Table 3 Correlation coefficients of soil $\mathrm{C}, \mathrm{N}$, and $\mathrm{P}$ concentrations, storage, and stoichiometry in subtropical forests in southern China.

\begin{tabular}{|c|c|c|c|c|c|c|c|c|c|}
\hline Properties & $\mathrm{SOC}$ & $\mathrm{TN}$ & TP & $\mathrm{C}_{\mathrm{S}}$ & $\mathrm{N}_{\mathrm{S}}$ & $\mathrm{P}_{\mathrm{S}}$ & $\mathrm{C}: \mathrm{N}$ & $\mathrm{C}: \mathrm{P}$ & $\mathrm{N}: \mathrm{P}$ \\
\hline $\mathrm{TN}$ & $0.83^{* *}$ & $1.00^{* *}$ & & & & & & & \\
\hline $\mathrm{TP}$ & $0.26^{* *}$ & $0.30^{* *}$ & $1.00^{* *}$ & & & & & & \\
\hline $\mathrm{C}_{\mathrm{S}}$ & $0.91^{* *}$ & $0.74^{* *}$ & $0.25^{* *}$ & $1.00^{* *}$ & & & & & \\
\hline $\mathrm{N}_{\mathrm{S}}$ & $0.70^{* *}$ & $0.87^{* *}$ & $0.28^{* *}$ & $0.82^{* *}$ & $1.00^{* *}$ & & & & \\
\hline $\mathrm{P}_{\mathrm{S}}$ & 0.06 & 0.08 & $0.81^{* *}$ & $0.24^{* *}$ & $0.31^{* *}$ & $1.00^{* *}$ & & & \\
\hline $\mathrm{C}: \mathrm{N}$ & $0.57^{* *}$ & 0.06 & 0.03 & $0.53^{* *}$ & -0.01 & -0.04 & $1.00^{* *}$ & & \\
\hline$C: P$ & $0.81^{* *}$ & $0.62^{* *}$ & $-0.32^{* *}$ & $0.72^{* *}$ & $0.49^{* *}$ & $-0.42^{* *}$ & $0.55^{* *}$ & $1.00^{* *}$ & \\
\hline$N: P$ & $0.58^{* *}$ & $0.71^{* *}$ & $-0.42^{* *}$ & $0.50^{* *}$ & $0.60^{* *}$ & $-0.50^{* *}$ & 0.02 & $0.83^{* *}$ & $1.00^{* *}$ \\
\hline
\end{tabular}

SOC, TN, TP, Cs, Ns, Ps, C:N, C:P, N:P, BD, and MC denote soil organic carbon, soil total nitrogen, soil total phosphorus, storage of soil organic carbon, storage of soil total nitrogen, storage of soil total phosphorus, C:N ratio, C:P ratio, N:P ratio, soil bulk density, and soil moisture concentrations, respectively. ${ }^{*}$ Significant difference at $P<0.05$; ** Significant difference at $P<0.01$. 
Biogeosciences Discuss., https://doi.org/10.5194/bg-2017-408

Manuscript under review for journal Biogeosciences

Discussion started: 23 October 2017

(c) Author(s) 2017. CC BY 4.0 License.

Table 4 Multiple linear regression of SOC, TN, and TP concentrations with stand characteristics, topography variables, and soil properties in 0-30 cm soil layers in subtropical forests in southern China. Stand characteristics are Shannon index, tree species number, stand density, average stand DBH, evergreen proportion (E), deciduous proportion (D), and litter biomass. Soil properties are soil $\mathrm{pH}$ value, soil bulk density (BD), soil moisture concentrations (MC), clay content, and silt content. The topography variables are elevation and convexity. Explanatory terms are listed in order of entering the models, and type I sums of squares are reported. DF, degree of freedom; MS, mean squared. Values in bold font indicate significant effect at $P$ $<0.05$.

\begin{tabular}{|c|c|c|c|c|c|c|c|c|c|c|c|c|}
\hline \multirow{2}{*}{ Variables } & \multicolumn{4}{|c|}{ SOC } & \multicolumn{4}{|c|}{$\mathbf{T N}$} & \multicolumn{4}{|c|}{ TP } \\
\hline & $\mathrm{DF}$ & MS & $\mathrm{F}$ & $\mathrm{P}$ & $\mathrm{DF}$ & MS & $\mathrm{F}$ & $\mathrm{P}$ & DF & MS & $\mathrm{F}$ & $\mathrm{P}$ \\
\hline $\begin{array}{c}\text { Shannon } \\
\text { index }\end{array}$ & 1 & 121.90 & 3.27 & 0.072 & 1 & 1.20 & 6.38 & 0.012 & 1 & 0.03 & 4.91 & 0.028 \\
\hline Richness & 1 & 34.70 & 0.93 & 0.335 & 1 & 0.13 & 0.69 & 0.408 & 1 & 0.00 & 0.11 & 0.746 \\
\hline Density & 1 & 508.40 & 13.64 & $<0.001$ & 1 & 1.79 & 9.49 & 0.002 & 1 & 0.08 & 13.65 & $<0.001$ \\
\hline $\mathrm{DBH}$ & 1 & 90.60 & 2.43 & 0.120 & 1 & 0.11 & 0.59 & 0.444 & 1 & 0.02 & 3.82 & 0.052 \\
\hline $\mathrm{E}$ & 1 & 19.50 & 0.52 & 0.470 & 1 & 0.01 & 0.06 & 0.811 & 1 & 0.00 & 0.00 & 0.995 \\
\hline D & 1 & 64.50 & 1.73 & 0.189 & 1 & 0.20 & 1.05 & 0.307 & 1 & 0.01 & 1.07 & 0.302 \\
\hline Litter biomass & 1 & 157.50 & 4.23 & 0.041 & 1 & 0.73 & 3.89 & 0.049 & 1 & 0.04 & 7.00 & 0.009 \\
\hline $\mathrm{PH}$ & 1 & 791.80 & 21.25 & $<0.001$ & 1 & 5.28 & 28.10 & $<0.001$ & 1 & 0.03 & 4.84 & 0.029 \\
\hline $\mathrm{BD}$ & 1 & 1171.70 & 31.44 & $<0.001$ & 1 & 4.96 & 26.37 & $<0.001$ & 1 & 0.05 & 8.31 & 0.004 \\
\hline $\mathrm{MC}$ & 1 & 6.10 & 0.16 & 0.686 & 1 & 0.33 & 1.75 & 0.187 & 1 & 0.00 & 0.08 & 0.773 \\
\hline Clay & 1 & 321.00 & 8.62 & 0.004 & 1 & 1.10 & 5.85 & 0.016 & 1 & 0.06 & 10.58 & $<0.001$ \\
\hline Silt & 1 & 0.80 & 0.02 & 0.887 & 1 & 0.55 & 2.94 & 0.087 & 1 & 0.10 & 18.57 & $<0.001$ \\
\hline Elevation & 1 & 204.30 & 5.48 & 0.020 & 1 & 5.07 & 26.96 & $<0.001$ & 1 & 0.01 & 1.58 & 0.210 \\
\hline Convexity & 1 & 20.20 & 0.54 & 0.462 & 1 & 0.02 & 0.10 & 0.751 & 1 & 0.00 & 0.01 & 0.920 \\
\hline Residuals & 260 & 37.30 & & & 260 & 0.19 & & & 260 & 0.01 & & \\
\hline
\end{tabular}


Biogeosciences Discuss., https://doi.org/10.5194/bg-2017-408

Manuscript under review for journal Biogeosciences

Discussion started: 23 October 2017

(c) Author(s) 2017. CC BY 4.0 License.

Table 5 Multiple linear regression of soil organic carbon storage $\left(\mathrm{C}_{\mathrm{S}}\right)$, nitrogen storage $\left(\mathrm{N}_{\mathrm{S}}\right)$, and phosphorus storage $\left(\mathrm{P}_{\mathrm{s}}\right)$ with stand characteristics, topography variables, and soil properties in 0-30 cm soil layers in subtropical forests in southern China. Stand characteristics are Shannon index, tree species number, stand density, average stand DBH, evergreen proportion (E), deciduous proportion (D), and litter biomass. Soil properties are soil $\mathrm{pH}$ value, soil bulk density (BD), soil moisture concentrations (MC), clay content, and silt content. The topography variables are elevation and convexity. Explanatory terms are listed in order of entering the models, and type I sums of squares are reported. DF, degree of freedom; MS, mean squared. Values in bold font indicate significant effect at $P<0.05$.

\begin{tabular}{|c|c|c|c|c|c|c|c|c|c|c|c|c|}
\hline \multirow{2}{*}{ Variables } & \multicolumn{4}{|c|}{$\mathrm{C}_{\mathrm{s}}$} & \multicolumn{4}{|c|}{$\mathbf{N}_{\mathbf{S}}$} & \multicolumn{4}{|c|}{$\mathbf{P}_{\mathrm{S}}$} \\
\hline & DF & MS & $\mathrm{F}$ & $\mathrm{P}$ & DF & MS & F & $\mathrm{P}$ & $\mathrm{DF}$ & MS & $\mathrm{F}$ & $\mathrm{P}$ \\
\hline $\begin{array}{c}\text { Shannon } \\
\text { index }\end{array}$ & 1 & 544.00 & 2.08 & 0.150 & 1 & 2.54 & 1.67 & 0.197 & 1 & 0.30 & 8.17 & 0.005 \\
\hline Richness & 1 & 734.00 & 2.81 & 0.095 & 1 & 5.37 & 3.54 & 0.061 & 1 & 0.00 & 0.02 & 0.883 \\
\hline Density & 1 & 6357.00 & 24.34 & $<0.001$ & 1 & 35.45 & 23.36 & $<0.001$ & 1 & 1.63 & 43.70 & $<0.001$ \\
\hline DBH & 1 & 321.00 & 1.23 & 0.269 & 1 & 1.09 & 0.72 & 0.397 & 1 & 0.00 & 0.02 & 0.877 \\
\hline E & 1 & 189.00 & 0.72 & 0.396 & 1 & 1.52 & 1.00 & 0.318 & 1 & 0.00 & 0.00 & 0.995 \\
\hline D & 1 & 37.00 & 0.14 & 0.707 & 1 & 0.06 & 0.04 & 0.840 & 1 & 0.01 & 0.22 & 0.638 \\
\hline $\begin{array}{c}\text { Litter } \\
\text { biomass }\end{array}$ & 1 & 897.00 & 3.44 & 0.065 & 1 & 8.45 & 5.57 & 0.019 & 1 & 0.22 & 5.90 & 0.016 \\
\hline $\mathrm{PH}$ & 1 & 2672.00 & 10.23 & 0.002 & 1 & 7.10 & 4.68 & 0.031 & 1 & 0.76 & 20.31 & $<0.001$ \\
\hline $\mathrm{BD}$ & 1 & 1835.00 & 7.03 & 0.009 & 1 & 10.72 & 7.04 & 0.001 & 1 & 3.44 & 92.62 & $<0.001$ \\
\hline $\mathrm{MC}$ & 1 & 586.00 & 2.24 & 0.135 & 1 & 0.52 & 0.35 & 0.557 & 1 & 0.01 & 0.18 & 0.670 \\
\hline Clay & 1 & 3787.00 & 14.50 & $<0.001$ & 1 & 17.95 & 11.83 & $<0.001$ & 1 & 0.24 & 6.35 & 0.012 \\
\hline Silt & 1 & 258.00 & 0.99 & 0.321 & 1 & 3.51 & 2.32 & 0.129 & 1 & 0.18 & 4.84 & 0.029 \\
\hline Elevation & 1 & 4396.00 & 16.83 & $<0.001$ & 1 & 8.88 & 5.85 & 0.021 & 1 & 0.20 & 5.34 & 0.022 \\
\hline Convexity & 1 & 22.00 & 0.09 & 0.769 & 1 & 0.09 & 0.06 & 0.812 & 1 & 0.27 & 7.29 & 0.007 \\
\hline Residuals & 260 & 261.00 & & & 260 & 1.52 & & & 260 & 0.04 & & \\
\hline
\end{tabular}


Biogeosciences Discuss., https://doi.org/10.5194/bg-2017-408

Manuscript under review for journal Biogeosciences

Discussion started: 23 October 2017

(c) Author(s) 2017. CC BY 4.0 License.

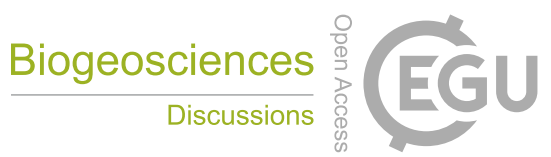

(c) (i)

\section{Figure Captions}

Fig. 1 Mean values of SOC (A), TN (B), and TP (C) concentrations for soils in different forests, bars indicate the standard error. Different lowercase letters indicate significant differences $(P<0.05)$ among forests at a given soil depth. PM-LG, Pinus massoniana - Lithocarpus glaber forest; CA, Choerospondias axillaris forest; LG-CG, L. glaber - Cyclobalanopsis 5 glauca forest.

Fig. 2 Mean values of SOC (A), TN (B), and TP (C) storage for soils in different forests, bars indicate the standard error. Different lowercase letters indicate significant differences $(P<0.05)$ among forests at a given soil depth. PM-LG, Pinus massoniana - Lithocarpus glaber forest; CA, Choerospondias axillaris forest; LG-CG, L. glaber - Cyclobalanopsis glauca 10 forest.

Fig. 3 Mean values of C:N (A), C:P (B), and N:P (C) ratio for soils in different forests, bars indicate the standard error. Different lowercase letters indicate significant differences $(P<0.05)$ among forests at a given soil depth. PM-LG, Pinus massoniana - Lithocarpus glaber forest; CA, Choerospondias axillaris forest; LG-CG, L. glaber - Cyclobalanopsis glauca forest. 
Biogeosciences Discuss., https://doi.org/10.5194/bg-2017-408

Manuscript under review for journal Biogeosciences

Discussion started: 23 October 2017

(c) Author(s) 2017. CC BY 4.0 License.

\section{Figure 1}
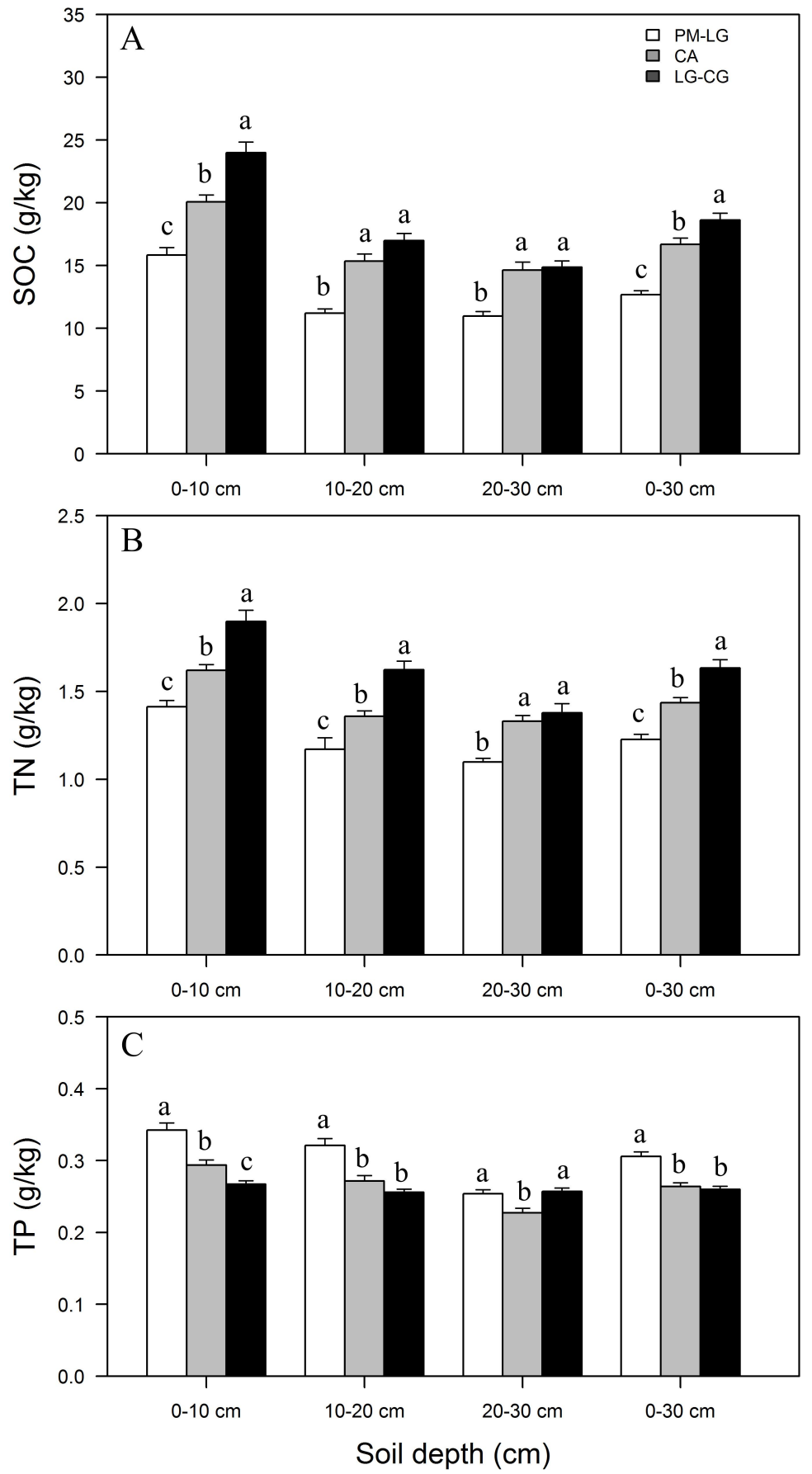
Biogeosciences Discuss., https://doi.org/10.5194/bg-2017-408

Manuscript under review for journal Biogeosciences

Discussion started: 23 October 2017

(C) Author(s) 2017. CC BY 4.0 License.

(C) (1)

Figure 2
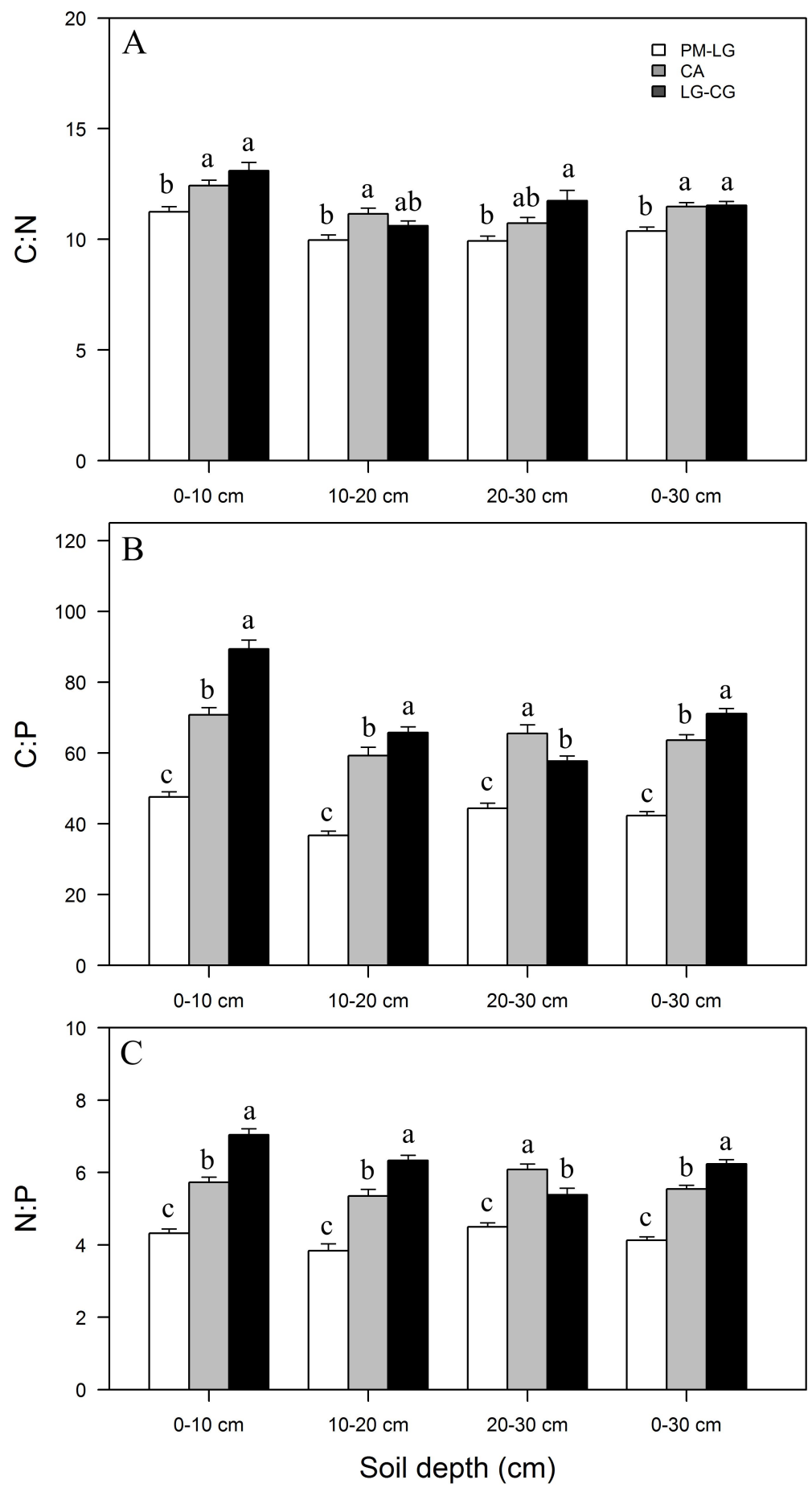
Biogeosciences Discuss., https://doi.org/10.5194/bg-2017-408

Manuscript under review for journal Biogeosciences

Discussion started: 23 October 2017

(c) Author(s) 2017. CC BY 4.0 License.

(C) (1)

Figure 3
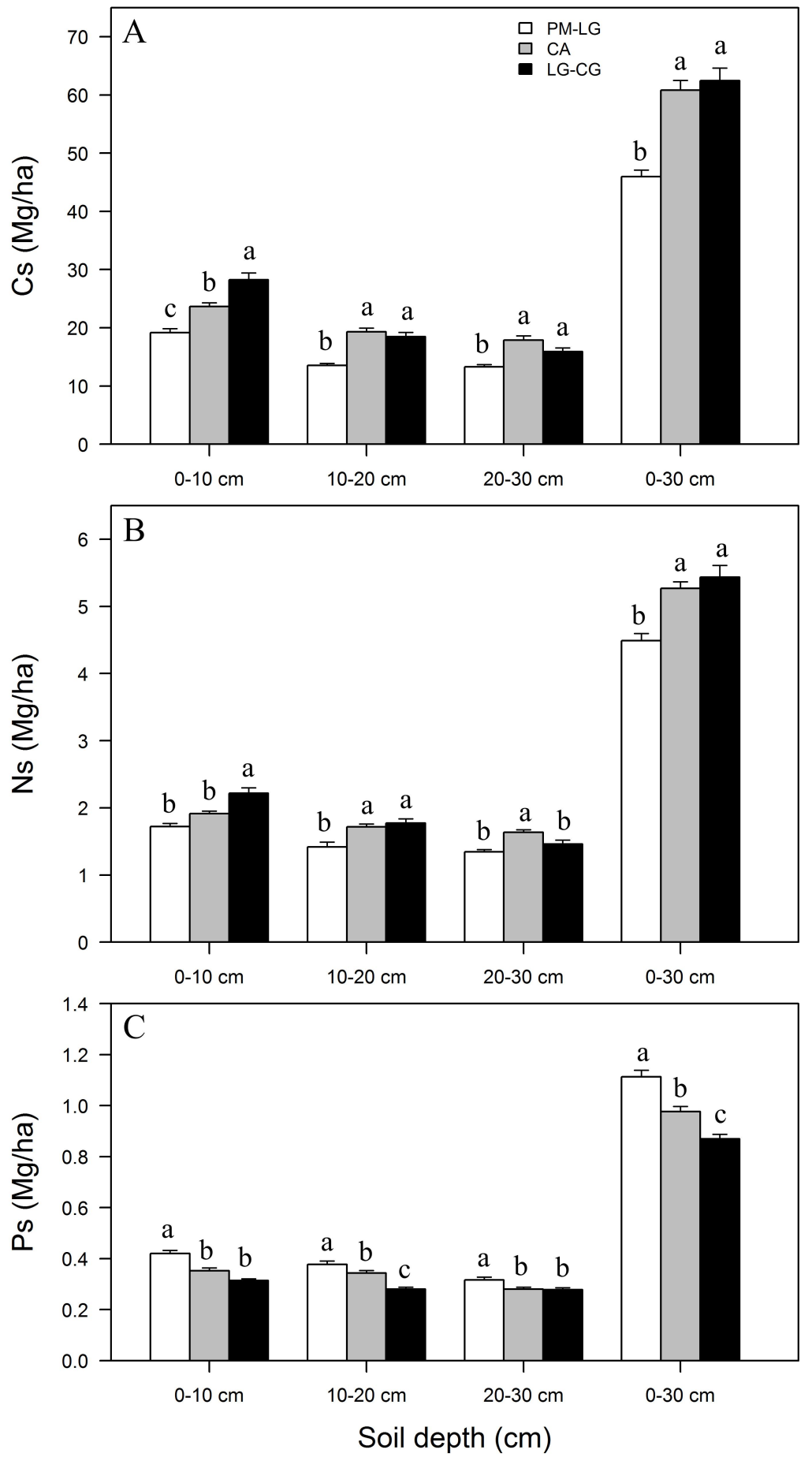